\title{
Плио-плейстоценовые герпетофауны окрестностей села Коротояк (Воронежская область)
}

\author{
○2020 В. Ю. Ратников ${ }^{凶}$ \\ Воронежский государственный университет, \\ Университетская пл., 1, 394018, Воронеж, Российская Федерация
}

\begin{abstract}
Аннотация
Введение: На юго-восточной окраине села Коротояк (Воронежская область) в трех местонахождениях разного возраста (Коротояк-1, Коротояк-3 и Коротояк-4) найдены остатки земноводных и пресмыкающихся. Целью статьи является информация о результатах определения этих остатков и их интерпретация.

Систематическая часть. Приводятся описания и идентификация найденных костей амфибий и рептилий.

Обсуждение и выводы. Всего две кости, идентифицированные как Pelophylax ridibundus и Natrix sp., происходят из местонахождения Коротояк-1 позднеплиоценового возраста. В раннеэоплейстоценовом местонахождении Коротояк-3 были определены Palaeobatrachus sp. - 1, Bufo sp. - 2, Anura indet. - 2, Lacertidae indet. - 1, Serpentes indet. - 2. Коллекция Коротояк-4 мучкапского возраста включает Bombina sp. - 1, Pelobates sp. - 5, Palaeobatrachus sp. - 1, Bufo verrucosissimus - 1, Bufo sp. - 3, Pelophylax ridibundus -1 , Rana temporaria - 2, Rana sp. - 1, Ranidae indet. - 3, Lacerta cf. agilis - 1, Elaphe dione - 2, Colubridae indet. - 1, Vipera sp. - 1. Остатки амфибий и рептилий во всех местонахождениях говорят о благоприятных условиях среды во время их формирования. Находки остатков Bufo sp. и Palaeobatrachus sp. свидетельствуют о сравнительно влажных лесных условиях во время формирования местонахождения Коротояк-3. Герпетофауна местонахождения Коротояк-4 позволяет предположить существование лиственного или смешанного леса и более теплый по сравнению с нынешним климат. В ее составе найдены современные виды, ареалы которых находятся вдалеке от местонахождения. Bufo verrucosissimus обитает ныне на Кавказе. Северная граница ареала Elaphe dione в настоящее время проходит через Ростовскую область. Сфенэтмоид палеобатрахуса найден на территории Восточно-Европейской равнины впервые. Этот экземпляр в деталях отличается от всех находок сфенэтмоидов в Западной и Центральной Европе. Однако из-за невозможности оценить изменчивость этого элемента скелета он определен только до родового уровня. Три фрагмента этой коллекции имеют патологические изменения: срастание позвонков у чесночницы и утолщение под котилярным ободом на позвонках узорчатого полоза и гадюки.

Ключевые слова: плиоцен, плейстоцен, амфибии, рептилии, остеология, палеогеография, остеопатология.

Для циттирования: Ратников В. Ю. Плио-плейстоценовые герпетофауны окрестностей села Коротояк (Воронежская область) // Вестник Воронежского государственного университета. Серия: Геология. 2020. №4. С. 12-25. DOI: doi.org/10.17308/geology.2020.4/3123
\end{abstract}

Ратников Вячеслав Юрьевич, e-mail: vratnik@yandex.ru 


\section{Введение}

Юго-восточная окраина села Коротояк Острогожского района Воронежской области оказалась богата остатками мелких позвоночных. Здесь, на правом берегу Дона, по оврагам вскрываются аллювиальные отложения как самого Дона, так и его правого притока, реки Тихая Сосна, включающие целый ряд местонахождений фауны. Некоторые из разрезов выбраны в качестве гипостратотипов для различных горизонтов [1]. Мелкие млекопитающие, полученные из местонахождений (Коротояк-1, Коротояк-2, Коротояк-3 и Коротояк-4), изучались А. К. Агаджаняном. В трех из них (Коротояк-1, Коротояк-3 и Коротояк-4) были встречены остатки земноводных и пресмыкающихся, любезно переданные мне для изучения. Описание разрезов с указанием местоположений ископаемых фаун мелких позвоночных приведены в монографии А. К. Агаджаняна [2].

Коротояк-1 - местонахождение из самого древнего, плиоценового [2, 3] стратиграфического уровня, в соответствии с новой стратиграфической схемой [1] датируемого верхним плиоценом. Разрез Коротояк-3, содержащий раннетаманский комплекс мелких млекопитающих [2, 3], предложен в качестве гипостратотипа для ногайского (самого древнего) горизонта верхнего эоплейстоцена $[1,4]$. Фауна местонахождения Коротояк-4 происходит из надморенных отложений и соответствует поздним фазам развития тираспольского комплекса мелких млекопитающих. Аналогичный эволюционный уровень в бассейне Верхнего Дона имеют несколько микротериофаун мучкапского возраста [2, 3].

\section{Систематическая часть}

Количество и систематический состав остатков герпетофауны различаются во всех трех местонахождениях и представлены в таблице 1. Ниже приводится описание костных остатков с использованием ранее употреблявшейся терминологии [5-7].

Табл. 1. Систематический состав герпетофаун в местонахождениях.

[Table 1. Systematic composition of herpetofauna in localities.]

\begin{tabular}{|c|c|c|c|}
\hline $\begin{array}{l}\text { Таксоны } \\
\text { [Taxons] }\end{array}$ & $\begin{array}{c}\text { Коротояк-1 } \\
\text { [Korotoyak-1] }\end{array}$ & $\begin{array}{c}\text { Коротояк-3 } \\
{[\text { Korotoyak-3] }}\end{array}$ & $\begin{array}{c}\text { Коротояк-4 } \\
\text { [Korotoyak-4] }\end{array}$ \\
\hline Bombina sp. & & & 1 \\
\hline Pelobates sp. & & & 5 \\
\hline Palaeobatrachus sp. & & 1 & 1 \\
\hline Bufo verrucosissimus (Pallas, 1814) & & & 1 \\
\hline Bufo sp. & & 1 & 3 \\
\hline Pelophylax ridibundus (Pallas, 1771) & 1 & & 1 \\
\hline Rana temporaria Linnaeus, 1758 & & & 2 \\
\hline Rana sp. & & & 1 \\
\hline Ranidae indet. & & & 3 \\
\hline Anura indet. & & 2 & \\
\hline Lacerta cf. agilis Linnaeus, 1758 & & & 1 \\
\hline Lacertidae indet. & & 1 & \\
\hline Elaphe dione (Pallas, 1773) & & & 2 \\
\hline Natrix sp. & 1 & & \\
\hline Colubridae indet. & & & 1 \\
\hline Vipera sp. & & & 1 \\
\hline Serpentes indet. & & 2 & \\
\hline Всего & 2 & 7 & 23 \\
\hline
\end{tabular}

КЛАСС АМРНІВІА Linnaeus, 1758

Отряд Anura Fischer von Waldheim, 1813

Семейство Bombinatoridae Gray, 1825

\section{Род Bombina Oken, 1816} Bombina sp.

Материал: Коротояк-4 - 1 подвздошная кость.

Ilium (рис. 1). Описываемый экземпляр соответствуем всем признакам рода, описанным нами ранее [8]. Крыло подвздошной кости тонкое, слабо изогнутое, без дорсального гребня. Верхний край acetabulum на одном уровне с дорсальным краем крыла. Дорсальная выпуклость очень высокая, лежит почти целиком позади переднего края ацетабулярной впадины. Tuber superior расположено на дорсальной выпуклости латерально. Pars descendens развита слабо, перегиб на её переднем крае не наблюдается. Таким образом, морфология верхней части тела кости напоминает морфологию

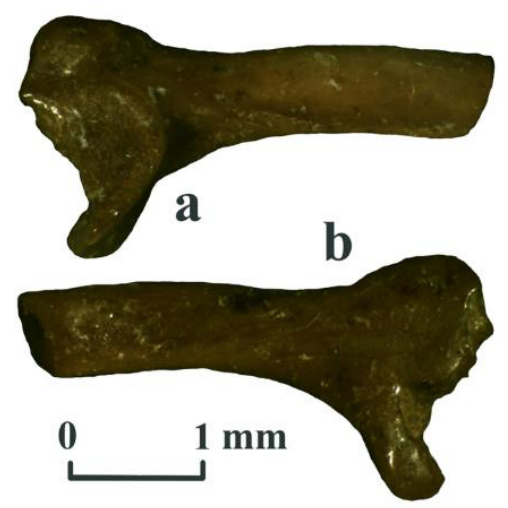

Рис. 1. Bombina sp., правая подвздошная кость (Коротояк-4): $a$-латерально, $b$ - медиально.

[Fig. 1. Bombina sp., right ilium (Korotoyak-4), $a$ - lateral view, $b$ - medial view.] 
Bombina bombina, а нижней - Bombina variegata [8] Учитывая перекрывающуюся изменчивость морфологии костей различных видов жерлянок, мы определяем данный образец только до рода, исключая при этом возможность идентификации его с видом Bombina orientalis из-за территориальной удаленности ареала последнего.

\section{Семейство Pelobatidae Bonaparte, 1850 Род Pelobates Wagler, 1830 Pelobates sp.}

Материал: Коротояк-4 - 1 атлас, 1 туловищный позвонок, 2 подвздошные кости, 1 кость голени.

Atlas (рис. 2 а-c). Этот образец демонстрирует срастание атласа со следующим туловищным позвонком. Невральная дуга атласа разрушена, два котилюса разделены. Кондилюс на процельном туловищном позвонке небольшой, немного сжатый дорсо-вентрально; медиальная часть невральной дуги с низким неврапофизом сильно оттянута назад.

Vertebra (рис. 2 d-e). Диагностика этого образца оказалась не простой из-за его разрушения. Сохранившаяся часть невральной дуги имеет сглаженную поверхность и не показывает диагностирующих особенностей. Наиболее значимой для идентификации оказалась форма диапофиза, у которого отломан конец. Прямо перед сломом диапофиз резко изгибается кверху, что характерно для четвертого позвонка Pelobates.

Ilium (рис. 2 f-g). Подвздошные кости чесночниц отличаются тем, что тело кости на медиальной стороне несет симфизную площадку, расположенную под углом к остальной медиальной поверхности, а крыло кости, без дорсального гребня, имеет на заднем конце с дорсальной стороны глубокую борозду. В отличие от ilia других семейств, у чесночниц эта кость не имеет видового диагностического значения, и поэтому наши образцы определены только до рода.

Tibiofibula. Это половина кости, обломанная на уровне отверстия для передней большеберцовой артерии. Здесь кость имеет округлую форму и быстро расширяется к концу; срединная борозда с одной стороны глубже, чем с другой. Диаметр сечения tibia меньше, чем fibula, эпифизы округлы. Такой морфологией обладают кости голени Pelobates [9].

\section{Семейство Palaeobatrachidae Cope, 1865 Род Palaeobatrachus Tschudi, 1838 Palaeobatrachus sp.}

Материал: Коротояк-3 - 1 уростиль , Коротояк-4 1 сфенэтмоид. .

Urostyle (рис. 2 k-n). Это длинная кость, образованная слиянием посткрестцовых позвонков. На переднем конце располагаются две слившиеся котилярные ямки, в которые вставлялся двойной кондилюс сакрального позвонка. С вентральной стороны от них располагается хорошо развитый processus intercondylicus [10]. На дор- сальной стороне располагалась невральная дуга, разрушенная на большей части описываемого образца, и ограничивавшая сверху и с боков невральный канал. На протяжении первого постсакрального позвонка этот канал значительно шире остальной его части, что отличает палеобатрахид от жаб и лягушек, у которых ширина канала на всем протяжении уростиля изменяется постепенно. Окончание невральной дуги первого постсакрального позвонка отмечается отверстиями в боковых стенках уростиля, через которые при жизни проходили задние спинномозговые нервы. Морфология образца сходна с описанием уростилей палеобатрахусов, происходящих из отложений Центральной и Западной Европы $[10,11]$.

Sphenethmoideum (рис. 2 h-j). Кость длиной 14 мм и шириной 9 мм, принадлежит очень крупному бесхвостому земноводному. Вентральная поверхность кости выпуклая, плавно закругленная, с узким желобом вдоль плоскости симметрии. На дорсальной поверхности имеется длинная узкая медиальная вырезка, открывающая узкую, длинную полость (antrum olfactorium) [12], в которой помещались обонятельные доли переднего мозга. В ее передней стенке имеются два небольших отверстия обонятельных каналов (canalis olfactorii), разделенных перегородкой и разворачивающихся вперед наподобие воронок. Каждый из каналов сопровождается дорсолатерально меньшим каналом для ramus medialis nervi ophthalmici [10]. Meдиальная вырезка закрывалась при жизни животного лобнотеменной костью. Поверхность контакта с ней оконтуривает медиальную вырезку, существенно расширяясь спереди и повторяя контур frontoparietale. Антеролатерально от заостряющегося конца лобнотеменной кости расположены две резко выраженные серповидные впадины, соответствующие контактам с носовыми костями $[12,13]$. В отличие от других семейств бесхвостых, на переднем конце сфенэтмоида которых выделяются ростральный и боковые отростки, на описываемом образце такие отростки не видны. Образец, несомненно, сходен по форме с описаниями и рисунками сфенэтмоидов палеобатрахид, найденных в Центральной и Западной Европе [10-14] и относимых сейчас [15] к одному роду Palaeobatrachus. Видовое определение образца затруднительно, так как описываемый экземпляр в деталях отличается от всех находок, указанных выше. Остатки палеобатрахид, происходящие из отложений Восточной Европы [16-23], как правило, фрагментарны и немногочисленны, и среди них еще не встречался сфенэтмоид. До настоящего времени они определялись как Pliobatrachus cf. langhae (из-за близости по возрасту с этим самым молодым видом из Восточной Европы), или как Pliobatrachus sp. Однако видовая идентификация, основанная на возрасте, а не морфологии, не корректна. В то же время, невозможность оценить изменчивость может привести к ошибочной идентификации. Поэтому описываемый образец определен как Palaeobatrachus sp. 


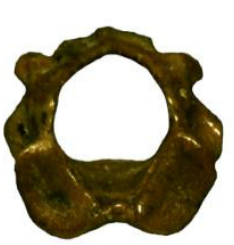

a

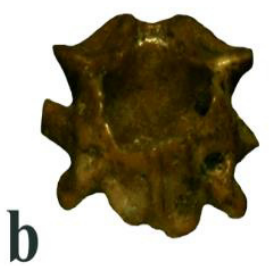

C
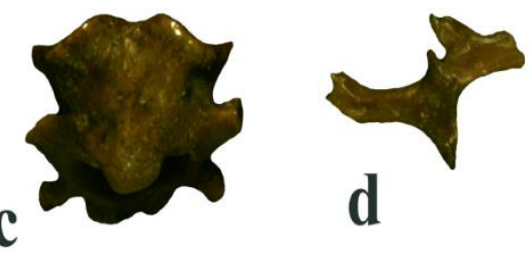

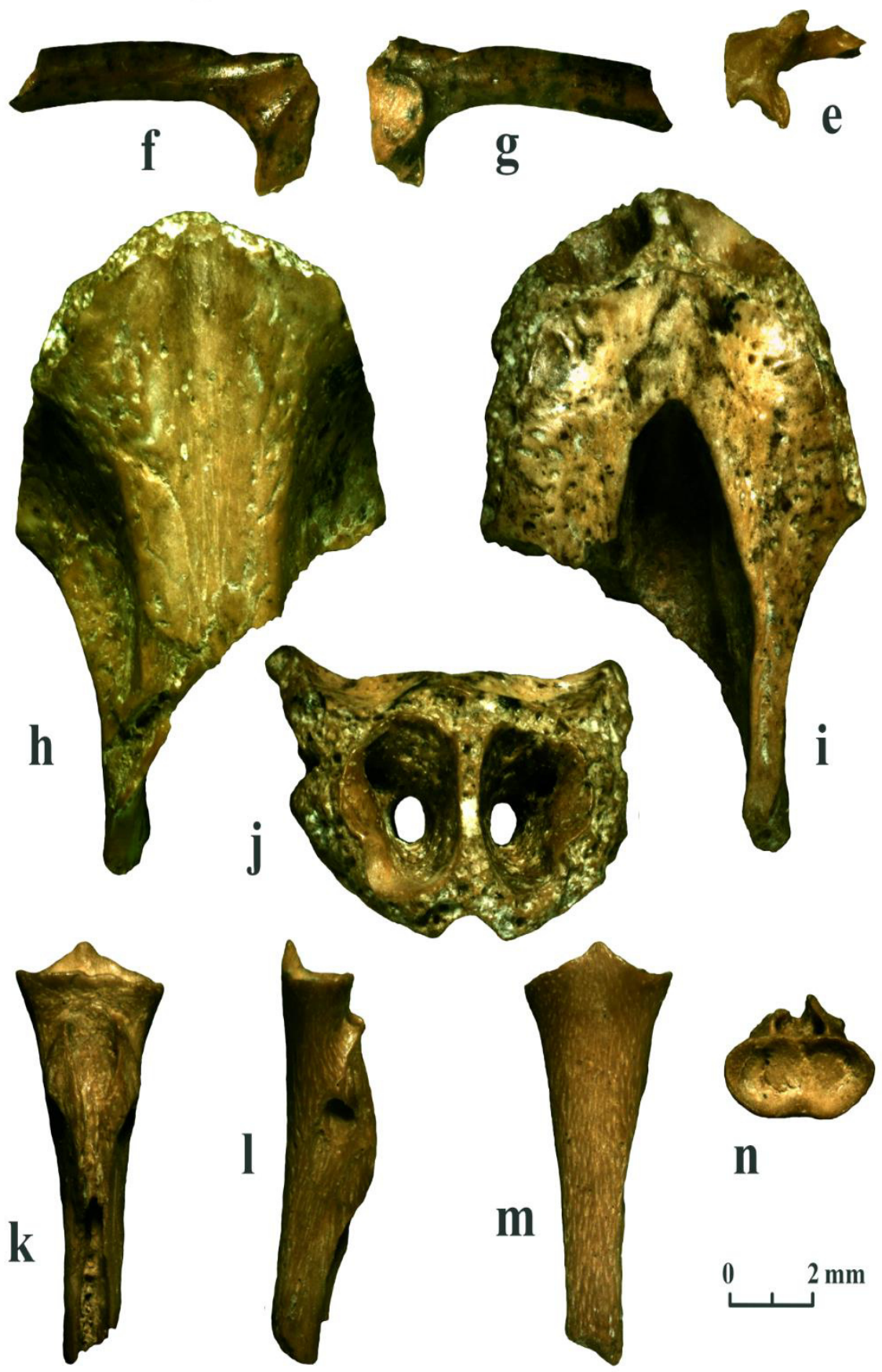

Рис. 2. Остатки Pelobates sp. (a-g) и Palaeobatrachus sp. (h-n): $a-c-$ сросшиеся атлас и второй позвонок (Коротояк-4): $a-$ спереди, $b$ - сверху, $c$ - снизу; $d$-e - четвертый позвонок (Коротояк-4): $d$ - спереди, $e$ - сверху; $f$ - $g$ - подвздошная кость (Коротояк-4): $f-$ медиально, $g$ - латерально; $h$-j - сфенэтмоид (Коротояк-4): $h$ - снизу, $i$ - сверху, $j$ - спереди; $k$ - $n$ - уростиль (Коротояк-3), $k$ - сверху, $l$ - сбоку, $m$ - снизу, $n$ - спереди.

[Fig. 2. Remains of Pelobates sp. (a-g) and Palaeobatrachus sp. (h-n): $a-c-$ the fused atlas and second vertebra (Korotoyak-4), $a-$ anterior view, $b$ - dorsal view, $c$ - ventral view; $d$ - $e$ - forth vertebra (Korotoyak-4): $d$ - anterior view, $e$ - dorsal view; $f$ - $g$ - ilium (Korotoyak-4): $f-$ medial view, $g$ - lateral view; $h-j$ - sphenethmoideum (Korotoyak-4): $h$ - ventral view, $i$ - dorsal view, $j$ - anterior view; $k-n$ - urostyle (Korotoyak-3): $k$ - dorsal view, $l$ - lateral view, $m$ - ventral view, $n$ - anterior view. 


\section{Семейство Bufonidae Gray, 1825 Род Bufo Garsault, 1764}

Bufo verrucosissimus (Pallas, 1814)

Материал: Коротояк-4 - 1 подвздошная кость.

Ilium (рис. 3 a-b). Это кость крупного животного, достигавшего при жизни длины около 80 см. Отсутствие дорсального гребня и преацетабулярной ямки в сочетании с толстым крылом кости свидетельствуют о принадлежности образца к серым жабам рода Bufo $[24,25]$. На территории Восточной Европы обитают два вида этого рода (обыкновенная жаба Bufo bufo и кавказская жаба Bufo verrucosissimus), отличающиеся формой вершинной шишки на подвздошных костях [24]. У изучаемого образца длинное, высокое tuber superior с неровной латеральной поверхностью, на которой наблюдаются 3 мелкие шишечки. Это сближает ископаемый экземпляр с Bufo verrucosissimus.

Bufo sp.

Материал: Коротояк-3 - 1 лопатка; Коротояк-4 - 1 бедренная кость, 2 кости голени.

Scapula (рис. 3 c-d). Хотя у кости разрушены и медиальный и латеральный концы, длина оставшейся части составляет 8 мм, что говорит об относительно крупных размерах животного. Facies lunata развернута наружу, pars lateralis и pars glenoidalis не перекрывают друг друга, что характеризует семейство Bufonidae [24, 25]. Размеры и пропорции фрагмента позволяют предположить его принадлежность к серым жабам, но определение вида не представляется возможным.

Femur. Сохранился только диафиз с большей частью хорошо развитого бедренного гребня, свидетельствующего о принадлежности к семейству Bufonidae $[24,25]$. Кость массивная, с толстыми стенками. Бедренный гребень сравнительно короткий, не переходит за середину кости, что позволяет отнести образец к роду Bufo [24]. Вблизи его дистального конца плохо различим дополнительный тупой гребень, который может присутствовать как у Bufo bufo, так и у Bufo verrucosissimus.

Tibiofibula. Несмотря на разрушенные эпифизы у одного из образцов, видно, что кость массивная, короткая, быстро расширяющаяся к концам и имеющая признаки семейства Bufonidae [24, 25]: у отверстия для передней большеберцовой артерии, приближенного к дистальному концу кости, имеется хорошо заметная борозда, переходящая в дистальном направлении в sulcus intermedius; в средней части кость сдавлена до формирования тупого киля, как со стороны tibia, так и со стороны fibula. Фрагмент принадлежал крупному животному (не менее 80 мм в длину), в связи с чем он определен как Bufo sp.. От второго образца сохранилась небольшая часть двух сросшихся костей (tibia+fibula?), быстро изменяющая ширину. Кроме этого, размеры фрагмента соответствуют другим костям жаб, найденным в местонахождении Коротояк-4.

\section{Семейство Ranidae Batsch, 1796 \\ Род Pelophylax Fitzinger, 1843}

Pelophylax ridibundus (Pallas, 1771)

Материал: Коротояк-1 - 1 плечевая кость; Коротояк-4 - 1 подвздошная кость.

Humerus (рис. 3 e-g). От кости сохранился дистальный фрагмент. След олекранона не смещен относительно длинной оси кости, а медиальный гребень не развернут дорсально, что позволяет отнести находку к зеленым лягушкам $[24,25]$. Край медиального гребня изгибается довольно резко, придавая ему неправильную форму. В наших сравнительных образцах такая форма не наблюдается у P. lessonae, тогда как близкие по очертаниям образцы встречаются среди $P$. ridibundus.

Ilium (рис. 3 h-i). Кость принадлежит мелкой особи и несет высокий дорсальный гребень, свидетельствующий о принадлежности экземпляра к семейству лягушек Ranidae [24, 25]. Наличие уплощенной поверхности на tuber superior, начинающейся довольно низко, сближает изучаемый образец с P. ridibundus [24].

\section{Род Rana Linnaeus, 1758}

Rana temporaria Linnaeus, 1758

Материал: Коротояк-4 - 2 плечевые кости. (Рис. Humerus)

Humeri (рис. 3 j-о). Оба экземпляра не имеют проксимальных частей. След олекранона не смещен относительно длинной оси кости - характеристика семейства Ranidae. Медиальный гребень развернут дорсально, что является признаком бурых лягушек [24, 25]. Латеральный гребень на одном образце проявляется в виде острого ребра, а на другом практически отсутствует. Эта особенность свойственна одному виду Восточной Европы - травяной лягушке Rana temporaria [24].

\section{Rana sp.}

Материал: Коротояк-4 - 1 плечевая кость.

Humerus (Рис. 3 p-r). Это дистальная часть кости с несмещенным следом олекранона. Медиальный и латеральный гребни отогнуты дорсально и сильно сближены друг с другом. К сожалению, разрушение кости не дает представления о длине гребней, которые кажутся деформированными.

\section{Ranidae indet.}

Материал: Коротояк-4 - 1 атлас, 1 бедренная кость, 1 кость голени.

Atlas (рис. 3 s-u). Два котилюса сообщаются между собой; невральная дуга сравнительно тонкая, в верхней части не полностью окостеневшая, в связи с чем ее правая и левая ветви разделены по медиальной линии глубоким желобом. Эти особенности являются признаками семейства Ranidae [24, 25]. Резкий рельеф ламин невральной дуги не совсем типичен для лягушек: у большинства из просмотренных мною сравнительных образцов он более сглажен. Хотя и резкий рельеф иногда наблюдается как у бурых, так и у зеленых лягушек. 

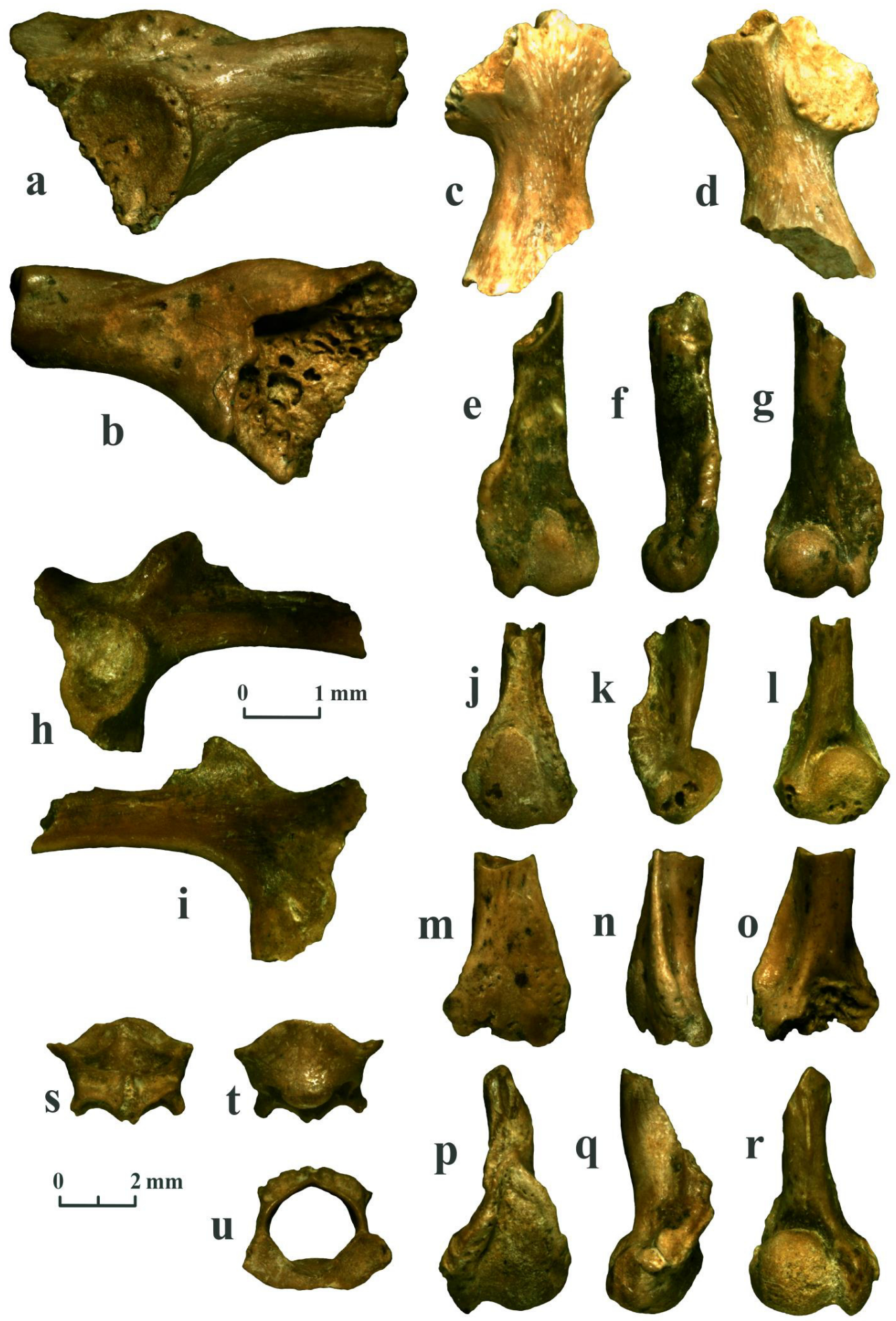

Рис. 3. Остатки жаб и лягушек. $a-b-$ Bufo verrucosissimus, правая подвздошная кость (Коротояк-4): $a-$ латерально, $b-$ медиально; $c-d$ - Bufo sp., правая лопатка (Коротояк-3): $c$ - изнутри, $d$ - снаружи; $e-i-$ Pelophylax ridibundus: $e-g$ - правая плечевая кость (Коротояк-1): $e$ - сверху, $f$ - медиально, $g$ - снизу; $h-i$ - правая подвздошная кость (Коротояк-4): $h$ - латерально, $i-$ медиально; $j$-o - Rana temporaria, левые плечевые кости (Коротояк-4): $j, m$ - сверху, $k, n$ - медиально, $l, o$ - снизу; $p$ - $r$ - Rana sp., правая плечевая кость (Коротояк-4): $p$ - сверху, $q$ - медиально, $r$ - снизу; $s$ - $u$ - Ranidae indet., атлас (Коротояк-4): $s$ - сверху, $t$ - снизу, $u$ - спереди.]

[Fig. 3. Remains of toads and frogs. $a-b-$ Bufo verrucosissimus, right ilium (Korotoyak-4): $a$ - lateral view, $b-$ medial view; $c-d-B u f o$ sp., right scapula (Korotoyak-3): $c$ - inner view, $d$ - auter view; $e-i-$ Pelophylax ridibundus: $e$ - $g$ - right humerus (Korotoyak-1): $e-$ dorsal view, $f$-medial view, $g$ - ventral view; $h-i$-right ilium (Korotoyak-4): $h$ - lateral view, $i$ - medial view; $j$-o - Rana temporaria, left humeral bones (Korotoyak-4): $j, m$ - dorsal view, $k, n$ - medial view, $l, o$ - ventral view; $p-r-$ Rana sp., right humerus (Korotoyak-4): $p-$ dorsal view, $q-$ medial view, $r$ - ventral view; $s$ - $u$ - Ranidae indet., atlas (Korotoyak-4): $s$ - dorsal view, $t$ - ventral view, $u$ - anterior view.] 
Femur. Сохранился только диафиз отчетливо Sобразной формы с дистальным концом плохо выраженного бедренного гребня, что говорит о принадлежности образца к семейству Ranidae [24, 25].

Tibiofibula. Это центральный фрагмент кости, на котором наблюдаются признаки семейства Ranidae [24, 25]: кость была длинная, медленно расширяющаяся к концам, в средней части округлого сечения с небольшим килем; с одной стороны, у отверстия для передней большеберцовой артерии имеется короткая борозда.

Anura indet.

Материал: Коротояк-3 - 1 сочленовная кость, 1 кость предплечья.

Оба фрагмента представляют собой задние части костей, которые позволяют понять, частями какой кости являются, но не дают возможности более близкого определения. Однако к Palaeobatrachidae они точно не принадлежат.

\section{КЛАСС DIAPSIDA Osborn, 1903 \\ Надотряд Squamata Oppel, 1811 Отряд Lacertilia Owen, 1842 \\ Семейство Lacertidae Oppel, 1811 Lacerta Linnaeus, 1758}

Lacerta cf. agilis Linnaeus, 1758

Материал: Коротояк-4 - 1 зубная кость.

Dentale (рис. 4 a-b). Это передняя часть кости, длиной 6.7 мм, несколько прогнутая вентрально и несущая плевродонтные зубы. На фрагменте сохранились 16 зубных позиций, из которых коронки сохранились на 2 и 13-15 позициях. Зубы цилиндрические, сжатые с боков, высокие, выступают над верхним краем кости на 1/3 длины зуба. Коронка переднего зуба одновершинная, коронки задних - двухвершинные, значительно крупнее передней. С медиальной стороны субдентальный гребень вогнут вентрально, согласно верхнему краю кости. Меккелев канал начинается от переднего края субдентального гребня и расширяется в заднем направлении. Гладкая латеральная поверхность пронизана шестью лабиальными отверстиями, причем предпоследнее отверстие является самым большим. Они расположены в одну линию в верхней половине зубной кости.

Описанные особенности характерны для представителей семейства настоящих ящериц Lacertidae [26, 27]. Ныне на территории Воронежской области обитают три вида из трех родов этого семейства: Eremias arguta, Zootoca vivipara и Lacerta agilis [28]. От dentale первого описываемый фрагмент отличается более плавным изгибом субдентального гребня, большей его шириной и менее загнутым передним концом кости, от второго - большими размерами. Размерами и морфологией он наиболее сходен с зубной костью третьего вида. Учитывая возможность нахождения южных форм значительно севернее их современных ареалов [29], было проведено сравнение нашего образца с Кавказским и Крымским видами рода Darevskia сходных размеров, Darevskia saxicola и Darevskia derjugini. От зубных костей обоих видов он отличается более крупными зубами и меньшим загибом переднего конца кости медиально. У более крупных по размеру ящериц моей сравнительной коллекции Lacerta media и Lacerta strigata оказалось по пять лабиальных отверстий. И, хотя количество отверстий может варьировать [27], кажется менее вероятным принадлежность образца какому-нибудь из этих видов. От Lacerta viridis описываемый фрагмент отличается относительно более широким субдентальным гребнем. Таким образом, несмотря на плохую сохранность, наиболее вероятна принадлежность образца к виду Lacerta agilis.

Lacertidae indet.

Материал: Коротояк-3 - 1 фрагмент верхнечелюстной кости.

Maxillare. Сохранилась небольшая часть супрадентального гребня с одним плевродонтным зубом и пятью зубными позициями на латеральной стенке кости. Зуб цилиндрический, сжатый с боков, высокий, выступает над верхним краем кости на $1 / 3$ своей длины. Вершина зуба окатана, но асимметрична, видимо, из-за первоначальной двухвершинности. Размеры зуба соответствуют ящерицам, сравнимым по размерам с $L a$ certa agilis.

\section{Отряд Serpentes Linnaeus, 1758 Семейство Colubridae Oppel, 1811 Подсемейство Colubrinae Oppel, 1811 Род Elaphe Fitzinger in Wagler, 1833 Elaphe dione (Pallas, 1773)}

Материал: Коротояк-4 - 2 позвонка.

Vertebrae. Оба позвонка не несут гипапофиз, что означает принадлежность к подсемейству Colubridae [30]. Centrum у первого позвонка (рис. 4 c-g) длинный, округлый снизу. Невральная дуга сзади невысокая, выпуклая. Гемальный киль сравнительно широкий, довольно высокий, округлый снизу, скорее шпателеобразный (sensu Auffenberg [31]); задний конец гемального киля плавно закруглен. Субцентральные гребни не развиты. Субцентральные отверстия маленькие и почти не заметны. Котилюс округлый. Паракотилярные отверстия маленькие. Субкотилярные шишечки отсутствуют. Справа от котилюса наблюдается частично разрушенное утолщение, скорее всего, патологического происхождения. Зигосфен слабо выпуклый спереди и, вероятно, трехраздельный сверху: его центральная доля разрушена. Неврапофиз разрушен, однако, судя по сохранившимся частям, не был высоким. Презигапофизальные сочленовные грани близкой к овальной формы. Презигапофизальные отростки широкие, с округлыми концами, в связи с чем выглядят короткими, направлены больше в стороны чем вперед. Постзигапофизальные сочленовные грани разрушены по краям и в настоящее время вытянутой формы. Интерзигапофизальные гребни почти параллельны оси centrum. Латеральные отверстия, лежащие в небольших впадинах, хорошо заметны. Разделение между пара- и диапофизальными сочленовными гранями 

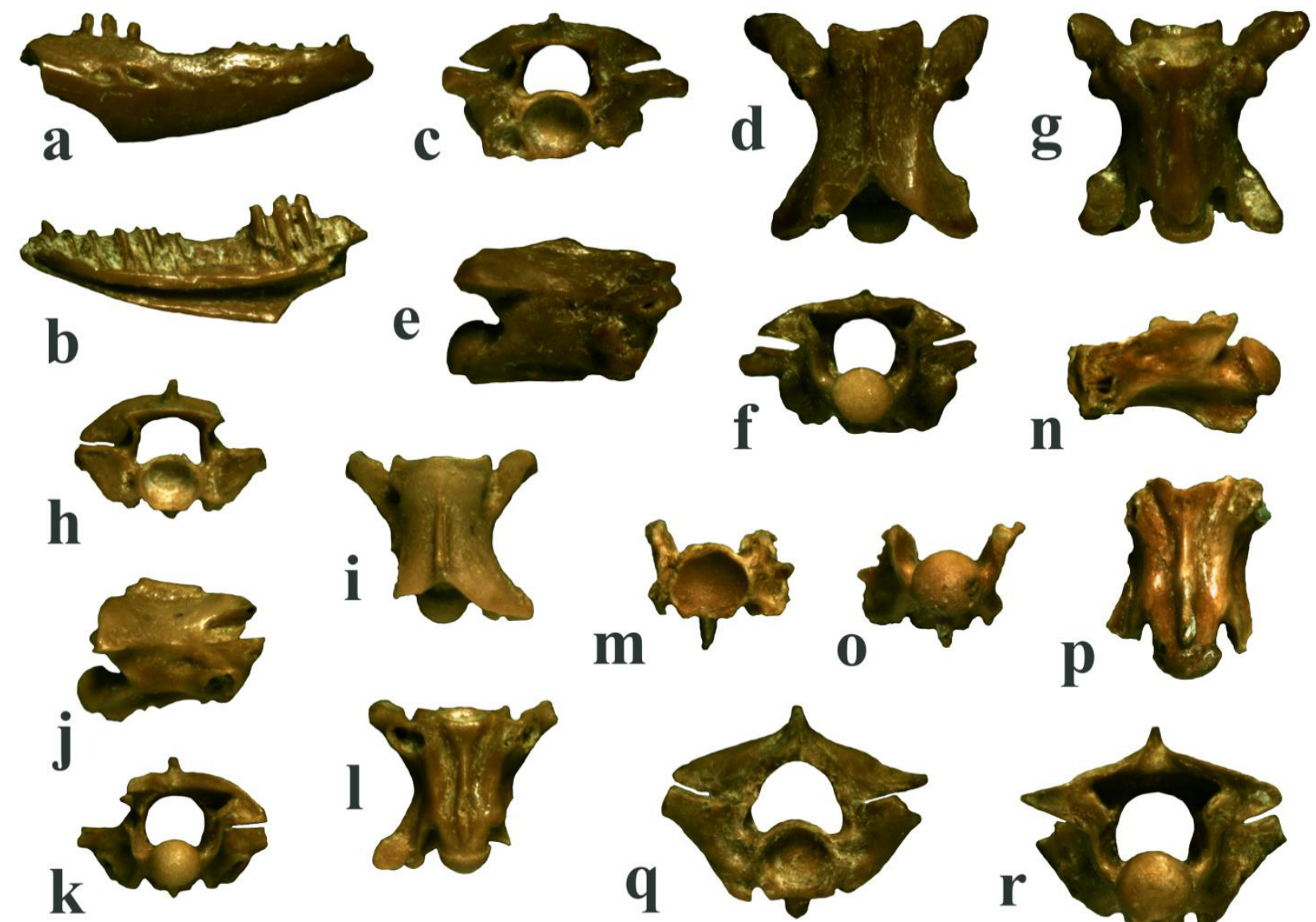

n
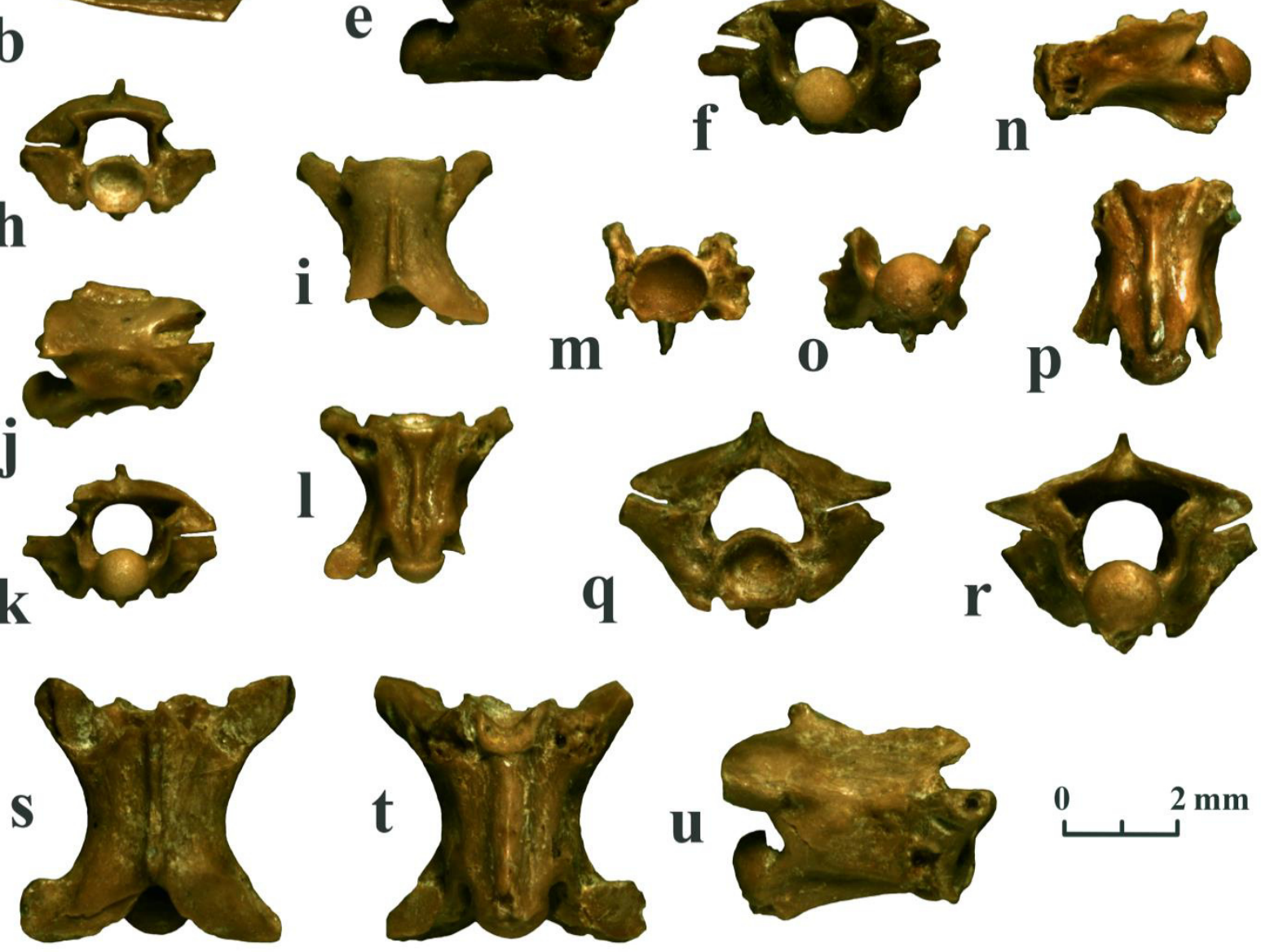

Рис. 4. Остатки рептилий. $a$ - $b$ - правая зубная кость Lacerta cf. agilis: $a$ - сбоку, $b$ - изнутри; $c$-l - позвонки Elaphe dione: $c$, $h-$ спереди, $d, i$ - сверху, $e, j$ - сбоку, $f, k$ - сзади, $g, l$ - снизу; $m$ - $p$ - позвонок Natrix sp.: $m$ - спереди, $n$ - сбоку, $o$ - сзади, $p$ - снизу; $q$ - $u$ - позвонок Vipera sp.: $q$ - спереди, $r$ - сзади, $s$ - сверху, $t$ - снизу, $u$-сбоку.

[Fig. 4. Remains of reptiles. $a$ - $b$ - right dentary of Lacerta $\mathrm{cf}$ agilis: $a$ - medial view, $b$ - lingual view; $c$ - $l$ - vertebrae of Elaphe dione: $c, h$ - anterior view, $d, i$ - dorsal view, $e, j$ - medial view, $f, k$ - posterior view, $g, l$ - ventral view; $m$ - $p$ - vertebra Natrix sp.: $m$ - anterior view, $n$ - medial view, $o$ - posterior view, $p$ - ventral view; $q$ - $u$ - vertebra Vipera sp.: $q$ - anterior view, $r$ - posterior view, $s$ - dorsal view, $t$ - ventral view, $u$ - medial view.]

слабо различимо. Парапофизы шире выпуклых диапофизов и выступают несколько впереди них. Своей морфологией данный образец наиболее близок Elaphe dione. Следует заметить, что изменчивость этого вида на самом деле значительно больше, чем предполагалось ранее [32], и широкие округлые презигапофизальные отростки были обнаружены автором в новых изученных сравнительных коллекциях Elaphe dione.

У второго позвонка (рис. 4 h-1) разрушены парадиапофизы, неврапофиз, презигапофизальные отростки и задняя часть невральной дуги слева. Это заднетуловищный позвонок, отличающийся рядом особенностей от передне- и среднетуловищных позвонков. Centrum длинный. Субцентральные гребни высокие, простираются от парапофизов до задних краев вертикальных пластин невральной дуги и отделены от гемального киля субцентральными желобами. Субцентральные отверстия не видны. Гемальный киль узкий, высокий, скорее мечевидный (sensu Auffenberg [31]) на виде снизу; его края в передней части centrum расходятся, ограничивая треугольную площадку, и сливаются с котилярным ободом. Котилюс округлый, с прямым нижним краем, ограниченным субкотилярными шишечками. Паракотилярные отверстия разной величины. 
Зигосфен выпуклый спереди и трехраздельный сверху с одинаково выступающими боковыми и центральной долями. Сохранившаяся постзигапофизальная сочленовная грань субчетырехугольной формы, презигапофизальные - вытянутой. Интерзигапофизальные гребни почти параллельны оси centrum. Латеральные отверстия, лежащие в небольших впадинах, хорошо заметны. Своей морфологией данный образец также наиболее близок Elaphe dione.

\section{Подсемейство Natricinae Bonaparte, 1838 Род Natrix Laurenti, 1768 Natrix sp.}

Материал: Коротояк-1 - 1 позвонок.

Vertebra (рис. 4 m-p). Образец очень плохой сохранности, с полностью разрушенной невральной дугой и парадиапофизами. Это сильно сокращает количество возможных критериев идентификации. Сохранившийся centrum (3.7 мм в длину) удлиненный, с относительно небольшими котилюсом и кондилюсом. Довольно глубокие субцентральные борозды, отделяют субцентральные гребни от гипапофиза. Передний киль уплощен, сильно расширяется к переднему концу и имеет форму почти равностороннего треугольника. Эти особенности позволяют исключить отнесение образца к Viperidae или Elapidae, которые характеризуются короткими телами позвонков и неразвитыми субцентральными гребнями [33]. Наличие гипапофиза также исключает отнесение образца к сравнимым по размерам Colubrinae, туловищные позвонки которых его не имеют [30], а шейные относительно короче. Таким образом, можно отнести образец к подсемейству Natricinae, представленному в Восточной Европе единственным родом Natrix. К сожалению, видовая диагностика образца невозможна.

Colubridae indet.

Материал: Коротояк-4 - 1 позвонок.

Vertebra. Это хвостовой позвонок с разрушенными плеврапофизами, зигосфеном, невральной дугой и неврапофизом. Невральная дуга высокая, массивная, что позволяет отнести образец к семейству Colubridae. Более близкая идентификация затруднена в связи с плохой сохранностью и нивелирования различий в хвостовых позвонках.

\section{Семейство Viperidae Oppel, 1811 Подсемейство Viperinae Oppel, 1811 Род Vipera Laurenti, 1768 Vipera sp.}

Материал: Коротояк-4 - 1 позвонок.

Vertebra (рис. q-u). Сохранность образца очень плохая: полностью разрушены зигосфен, парадиапофизы, презигапофизальные отростки и неврапофиз; пре- и постзигапофизальные сочленовные грани по краям сильно побиты; отсутствует часть гипапофиза позади от кондилюса. Длина тела centrum составляет 4.2 мм. Наличие гипапофиза, направленного назад, в сочетании с уплощенной невральной дугой, позво- ляет отнести образец к семейству Viperidae [30], из которого в настоящее время на территории Восточной Европы обитают только представители рода $\mathrm{Vi}$ pera [34]. Практически невозможна принадлежность этого позвонка подсемейству Crotalinae из-за слишком большого временного промежутка между фауной Коротояк-4 и фауной Грицев (MN9) на Украине, откуда были описаны первые и до сих пор единственные находки верхнечелюстных костей представителей этого подсемейства [35]. Наличие слабовыраженных субцентральных гребней говорит о том, что позвонок происходит из задней части туловища, а невыпуклые на виде сзади ламины сближают его больше с гадюками группы V. renardi, чем V. berus. Однако таких признаков недостаточно для уверенной идентификации вида. Кроме этого, медиальная вырезка невральной дуги сзади у описываемого образца уже, чем у сравнительных образцов обоих видов гадюк в нашей сравнительной коллекции. Поэтому образец определен как Vipera sp. Из его особенностей следует отметить наличие утолщения под нижней частью котилярного обода, не относящегося к элементам нормальной морфологии и являющегося, вероятно, результатом патологического изменения.

Serpentes indet.

Материал: Коротояк-3 - 2 позвонка.

Vertebrae. Один образец представляет собой заднюю часть тела позвонка с основанием гипапофиза. Кондилюс разрушен, но был, видимо, несколько приплюснут дорсовентрально. Нижняя поверхность выпуклая вблизи кондилюса, хотя впереди субцентральные гребни могли быть. Другой образец - фрагмент передней части тела позвонка, несущего гипапофиз. Передний киль сливается спереди с субкотилярным ободом, на котором наблюдаются небольшие субкотилярные шишечки. Информаци не достаточно для более точного определения этих фрагментов.

\section{Обсуждение и выводы}

Как видно из таблицы 1 , количество остатков холоднокровных наземных позвоночных сильно различается в разных местонахождениях. Всего две кости, идентифицированные как Pelophylax ridibundus и $\mathrm{Na}$ trix sp., происходят из местонахождения Коротояк-1. Несмотря на такое незначительное количество остатков, благоприятность климатической обстановки в то время несомненна. Впрочем, более подробная информация о приблизительно этом же времени в почти этом же месте была получена ранее $[9,18,20]$ из местонахождения Коротояк-белогорье.

В местонахождении Коротояк-3 костей собрано больше, хотя и плохой сохранности. Они были определены как: Palaeobatrachus sp. - 1, Bufo sp. - 2, Anura indet. -2 , Lacertidae indet. -1 , Serpentes indet. -2 . Надо заметить, что эоплейстоценовых герпетофаун на Восточно-Европейской равнине найдено мало. В частности, известно лишь две таманские фауны (Карай-Дубина и Крыжановка) с территории Северного Причер- 
номорья, которые существовали в условиях степного или лесостепного ландшафта [9]. Находки остатков серых жаб Bufo sp. - жителей закрытых биотопов, а также крупного водного бесхвостого земноводного Palaeobatrachus sp., свидетельствуют о более влажных, лесных условиях во время формирования местонахождения Коротояк-3. Кости ящериц в упомянутых выше таманских фаунах также не находили.

Наиболее крупной и разнообразной оказалась коллекция Коротояк-4, включающая 23 кости: Bombina sp. - 1, Pelobates sp. - 5, Palaeobatrachus sp. - 1, Bufo verrucosissimus - 1, Bufo sp. - 3, Pelophylax ridibundus - 1, Rana temporaria - 2, Rana sp. - 1, Ranidae indet. 3, Lacerta cf. agilis - 1, Elaphe dione - 2, Colubridae indet. - 1, Vipera sp. - 1. Здесь захоронились представители, как минимум, восьми семейств холоднокровных наземных позвоночных, что свидетельствует о весьма благоприятных условиях среды. Суммарное количество находок палеобатрахуса, серых жаб и травяных лягушек, превышающее суммарное количество чесночниц и прыткой ящерицы, позволяет предположить существование лиственного или смешанного леса. Северная граница ареала узорчатого полоза Elaphe dione в настоящее время проходит через Ростовскую область [34], что позволяет предположить более теплые климатические условия, чем в настоящее время. Ранее позвонки этой змеи были описаны из мучкапского местонахождения Козий Овраг [22], кстати, тоже располагающегося в пределах села Коротояк.

Жерлянки ранее встречались в мучкапских местонахождениях Вольная Вершина-1 [36], Кузнецовка [5, $37,38]$ и Кролятник [9], причем в первом из них наблюдалось большее сходство морфологии костей с Bombina variegata, а в двух других - с Bombina bombina. Подвздошная кость из Коротояка-4 сочетает в себе признаки обоих видов.

Количество остатков чесночниц в местонахождении уступает лишь количеству лягушек, правда определить их удалось только до рода. Один из образцов демонстрирует срастание атласа со следующим позвонком.

Мучкап - это последний временной интервал существования палеобатрахид, представленный в бассейне Верхнего Дона целым рядом местонахождений [5, 9, 15-17, 19, 37]. Теперь к ним добавилось еще одно.

Еще один современный вид, ареал которого в настоящее время далеко удален от местонахождения ископаемых остатков - кавказская жаба Bufo verrucosissimus. Как отмечалось ранее [37], эта жаба населяла территорию Восточно-Европейской равнины в позднем плиоцене и раннем и среднем плейстоцене, хотя достоверных находок ее не много [39]. Коротояк-4 третье мучкапское местонахождение этого вида.

Местонахождений озерной лягушки Pelophylax ridibundus значительно больше [39], хотя и с небольшим количеством остатков. До настоящего времени было известно только одно мучкапское местонахождение - Кузнецовка.
Травяная лягушка Rana temporaria часто встречается в местонахождениях верхнего плейстоцена-голоцена. В более древних отложениях находки этого вида редки [39]. В частности, она была найдена в двух местонахождениях мучкапского возраста в бассейне Верхнего Дона.

Прыткая ящерица Lacerta agilis встречена в довольно большом количестве местонахождений, хотя и в небольшом количестве экземпляров [39]. В большинстве случаев идентификация челюстных костей основывалась на сходстве размеров фоссилий с размерами соответствующих костей настоящих ящериц, обитающих ныне на территории Восточно-Европейской равнины: Lacerta agilis, Lacerta viridis и Zootocaa vivipara [9]. Однако находки южных видов ящериц далеко к северу от их современных ареалов $[29,36,40]$ делают такую идентификацию не достаточной. Здесь определение кости основывалось на морфологических признаках.

Позвонки гадюковых змей очень трудны для идентификации, особенно если они еще и повреждены. Позвонок из Коротояка-4 определить не удалось, хотя принадлежность его к роду Vipera удалось обосновать. Прежде гадюки были встречены в двух местонахождениях мучкапского возраста [39], в одном - обыкновенная, а в другом - степная.

Три фрагмента этой коллекции имеют патологические изменения: срастание позвонков у чесночницы и утолщение под котилярным ободом на позвонках узорчатого полоза и гадюки.

Благодарности: Автор выражает благодарность А. К. Агаджаняну (ПИН РАН) за предоставленный для изучения ископаемый материал.

Конфликт интересов: Автор декларирует отсутствие явных и потенциальных конфликтов интересов, связанных с публикацией настоящей статьи.

\section{ЛИТЕРАТУРА}

1. Шик С. М., Тесаков А. С., Агаджанян А. К., Иосифова Ю. И., Маркова А. К., Писарева В. В., Семенов В. В. Проект региональной стратиграфической шкалы эоплейстоцена и гелазия (палеоплейстоцен) центра и юга Европейской России // Бюллетень региональной межведомственной стратиграфической комиссии по Центру и Югу Русской платформы. 2015. Выпуск 6. С. 97-107.

2. Агаджанян А. К. Мелкие млекопитающие плиоцен-плейстоцена Русской равнины. М.: Наука, 2009. 676 с.

3. Агаджанян А. К., Глушанкова Н. И. Палеогеография плиоцен-плейстоцена верхнего Дона // Бюл. комис. по изуч. четвертич. периода. 1988. № 57. С. 62-77.

4. Шик С. М., Агаджанян А. К., Иосифова Ю. И., Маркова А. К., Писарева В. В., Семенов В. В., Тесаков А. С. Проект региональной стратиграфической шкалы эоплейстоцена центра и юго-востока Восточно-Европейской платформы // Фундаментальные проблемы квартера, итоги изучения и основные направления дальнейших исследований: Материалы IX Всероссийского совещания по изучению четвертичного периода (г. Иркутск, 15-20 сентября 2015 г.). С. 505-507.

5. Ратников В. Ю. Бесхвостые амфибии позднего кайнозоя Восточно-Европейской платформы и их стратиграфическое и палеогеографическое значение. Воронеж, 1994. 140 с. 
6. Szyndlar Z. Fossil snakes from Poland // Acta zool. cracov. 1984. V. 28. № 1. P. 1-156.

7. Evans S. E. The skull of lizards and Tuatara // Biology of the Reptilia. 2008. Vol. 20. The skull of Lepidosauria. P. 1-347.

8. Ратников В. Ю. К идентификации жерлянок (Bombina, Discoglossidae) по элементам скелета при палеонтологических исследованиях // Актуальные проблемы герпетологии и токсинологии: Сборник научных трудов. 2003. Вып. 6. С. 91-101.

9. Ратников В. Ю. Позднекайнозойские земноводные и чешуйчатые пресмыкающиеся Восточно-Европейской равнины. Труды научно-исследовательского института геологии. Воронеж: Изд-во Воронеж. гос. ун-та, Вып. 10. 2002. $138 \mathrm{c}$.

10. Villa A., Roček Z., Tschopp E., van den Hoek Ostende L. W., Delfino M. Palaeobatrachus eurydices, sp. nov. (Amphibia, Anura), the last Western European Palaeobatrachid // Journal of Vertebrate Paleontology. 2016. V. 36. № 6. P. 1-15.

11. Špinar Z. Tertiary Frogs from Central Europe. Prague: Academia, 1972. $286 \mathrm{p}$.

12. Hossini S., Rage J.-C. Palaeobatrachid frogs from the earliest Miocene (Agenian) of France, with description of a new species // Geobios. 2000. V. 33. № 2. P. 223-231.

13. Venczel M., Codrea V., Fărcaş C. A new palaeobatrachid frog from the early Oligocene of Suceag, Romania // Journal of Systematic Palaeontology. 2013. V. 11. № 2. P. 179-189.

14. Sanchiz B., Młynarski M. Remarks on the fossil anurans from the Polish Neogene // Acta zool. cracov. 1979. V. 24. № 1-4. P. 153-173.

15. Wuttke M., Přikryl T., Ratnikov V. Yu., Dvořák Z., Roček Z. Generic diversity and distributional dynamics of the Palaeobatrachidae (Amphibia: Anura) // Palaeobiodiversity and Palaeoenvironments. 2012. V. 92. № 3. P. 367-395.

16. Ратников В. Ю. Первая находка Pliobatrachus (Anura, Palaeobatrachidae) в мучкапских отложениях бассейна Верхнего Дона // Палеонт. журн. 1993. № 4. С. 130-132.

17. Ратников В. Ю. Раннеплейстоценовая герпетофауна из местонахождения Козий Овраг в бассейне Верхнего Дона // Изв. вузов. Геология и разведка. 1996. № 6. С. 16-19.

18. Ratnikov V. Yu. The Late Pliocene herpetofauna of the Korotoyak site the Voronezh region and the contemporary lanscape // The down of the Quaternary: Abstracts of the INQUASEQS symposium, 16-21 June 1996, Kerkrade, The Netherlands. P. 79.

19. Ратников В. Ю. О находках Pliobatrachus (Anura, Palaeobatrachidae) в Восточной Европе // Палеонт. журн. 1997. № 4. C. $70-76$.

20. Ratnikov V. Yu. Pliocene anurans of East-European platform // Russian journal of herpetology. 2001. V.8. № 3. P. 171-178.

21. Ratnikov V. Yu. Muchkapian (Early Neopleistocene) Amphibians and Reptiles of the East-European plain // Russian journal of herpetology. 2002. V.9. № 3. P. 229-236.

22. Ратников В. Ю. Новые находки земноводных и пресмыкающихся в опорных мучкапских местонахождениях бассейна Верхнего Дона // Вестник Воронежского государственного университета. Серия: Геология. 2002. № 1. С. 73-79.

23. Ратников В. Ю. Новые находки земноводных и пресмыкающихся из нижненеоплейстоценового местонахождения Ильинка // Вестник Воронежского государственного университета. Серия: Геология. 2003. № 1. С. 36-39.

24. Ratnikov V.Yu. Osteology of Russian toads and frogs for palaeontological researches // Acta zool. cracov. 2001. V. 44. № 1.
P. 1-23.

25. Ратников В. Ю. Остеологические характеристики надвидовых таксонов жаб и лягушек Восточной Европы // Bonpocbl герпетологии: материалы Пятого съезда Герпетологического общества им. А.М. Никольского, Минск, 25-28 сентября 2012 г. C. 269-273.

26. Čerňansky' A., Syromyatnikova E.V. The first Miocene fossils of Lacerta cf. trilineata (Squamata, Lacertidae) with a comparative study of the main cranial osteological differences in green lizards and their relatives // PLOS ONE. 2019. V.14. № 8: e0216191. P. 1-55.

27. Воробьева Э. И., Чугунова Т. Ю. Зубная система ящериц: таксономическое и экологическое разнообразие. М.: Наука, 1995. $151 \mathrm{c}$.

28. Гончаров А. Г. О распространении ящериц (Sauria) в Центральном Черноземье // Современная герпетология: проблемы и пути их решения. Статьи по материалам докладов первой международной молодежной конференции герпетологов России и сопредельных стран (Санкт-Петербург, Россия, 25-27 ноября 2013 г.). С. 72-76.

29. Ратников В. Ю. Герпетофауна из средненеоплейстоценового местонахождения Ручей Колябинский (Курская область) // Вестник Воронежского государственного университета. Серия: Геология. 2019. № 2. С. 36-42.

30. Szyndlar Z. A review of Neogene and Quaternary snakes of Central and Eastern Europe. Part II: Natricinae, Elapidae, Viperidae // Estudios geol. 1991. V.47. P. 237-266.

31. Auffenberg W. The fossil Snakes of Florida // Tulane Studies Zool. 1963. V. 10. № 3. P. 131-216.

32. Ratnikov V. Yu. Identification of some Eurasian species of Elaphe (Colubridae, Serpentes) on the basis of vertebrae // Russian Journal of Herpetology. 2004. V. 11. № 2. P. 91-98.

33. Ratnikov V., Mebert K. Fossil remains of Natrix tessellata from the Late Cenozoic deposits of the East European Plain // Mertensiella. 2011. № 18. P. 337-342.

34. Ананьева Н. Б., Орлов Н. Л., Халиков Р. Г., Даревский И. С., Рябов С. А., Барабанов А. В. Атлас пресмыкающихся Северной Евразии (таксономическое разнообразие, географическое распространение и природоохранный статус). СПб: Зоологический институт РАН, 2004. 232 с.

35. Ivanov M. The first European pit viper from the Miocene of Ukraine // Acta Palaeontologica Polonica. 1999. V. 44. № 3. P. 327-334.

36. Ратников В. Ю. Герпетофауна нижнеплейстоценового местонахождения Вольная Вершина в бассейне Верхнего Дона // Вестник Воронежского государственного университета. Серия: Геология. 1996. № 1. С. 90-93.

37. Ратников В. Ю. Эоплейстоценовые и плейстоценовые фауны бесхвостых земноводных Восточно-Европейской платформы // Палеонт. журн. 1992. № 1. С. 89-100.

38. Ратников В. Ю. Новые данные о герпетофауне местонахождения Кузнецовка в Тамбовской области // Изв. вузов. Геология и разведка. 1997. № 1. С. 26-32.

39. Ратников В. Ю. Ископаемые остатки современных видов земноводных и чешуйчатых пресмыкающихся как материал для изучения истории их ареалов // Труды научно-исследовательского института геологии Воронежского государственного университета. Вып. 59. Воронеж: изд-во Воронеж. унта, $2009.91 \mathrm{c}$

40. Ратников В. Ю. Герпетофауна верхнеплейстоценового местонахождения Еласы в бассейне Волги // Актуальные проблемы герпетологии и токсинологии: Сборник научных трудов, Вып. 5. Тольятти, 2001. С. 81-88. 


\title{
Plio-Pleistocene herpetofauna in the vicinity of Korotoyak village (Voronezh Region)
}

\author{
C 2020 V. Yu. Ratnikov ${ }^{凶}$ \\ Voronezh State University, 1 Universitetskaya pl., 394018, Voronezh, Russian Federation
}

\begin{abstract}
Introduction: Amphibian and reptile remains were found on the southeastern outskirts of Korotoyak (Voronezh Kegion) in three localities of different ages: Korotoyak-1, Korotoyak-3, and Korotoyak-4. The article describes the results of the analysis of these remains and their interpretation.

Methodology: The found bones of amphibians and reptiles were described and identified.

Results and discussion: Only two bones, identified as Pelophylax ridibundus and Natrix sp., were found at Korotoyak-1 of the Late Pliocene age. The bones found at the Early Eopleistocene locality Korotoyak-3 included Palaeobatrachus sp. (1 bone), Bufo sp. (2 bones), Anura indet. (2 bones), Lacertidae indet. (1 bone), and Serpentes indet. (2 bones). The Muchkap age Korotoyak-4 collection includes Bombina sp. (1 bone), Pelobates sp. (5 bones), Palaeobatrachus sp. (1 bone), Bufo verrucosissimus (1 bone), Bufo sp. (3 bones), Pelophylax ridibundus (1 bone), Rana temporaria (2 bones), Rana sp. (1 bone), Ranidae indet. ( 3 bones), Lacerta cf. agilis (1 bone), Elaphe dione (2 bones), Colubridae indet. (1 bone), and Vipera sp. (1 bone). The remains of amphibians and reptiles in all three localities indicate favourable environmental conditions during their formation. The remains of Bufo sp. and Palaeobatrachus sp. indicate that Korotoyak-3 was formed under relatively humid forest conditions. The herpetofauna of Korotoyak-4 suggests the existence of deciduous or mixed forests at the site and a warmer climate as compared to the current one. It appears that the herpetofauna included modern species, whose natural habitats are currently far from the site. Bufo verrucosissimus can now be found in the Caucasus. The northern border of the Elaphe dione habitat currently goes through the Rostov Region. The sphenethmoid bone of Paleobatrachus was found on the territory of the East European Plain for the first time. This specimen differs from all the sphenetmoid bones found in Western and Central Europe. However, we only managed to identify the genus of the specimen, since it is impossible to assess the variability of this skeleton element. Three fragments of this collection have pathological changes: ankylosis in the case of the spadefoot and thickening under the cotylar rim on the vertebrae of the steppe ratsnake and the viper.
\end{abstract}

Keywords: Pliocene, Pleistocene, amphibians, reptiles, osteology, paleogeography, osteopathology.

For citation: Ratnikov V. Yu. Plio-Pleistocene herpetofaunas in the vicinity of the Korotoyak village (Voronezh Region). Vestnik Voronezhskogo gosudarstvennogo universiteta. Seriya: Geologiya = Proceedings of Voronezh State University. Series: Geology, 2020, no. 4, pp. 12-25. DOI: doi.org/10.17308/geology.2020.4/3123

Acknowledgments: The author thanks to A.K. Agadzhanyan (PIN RAS) for the fossil material provided for study.

Conflict of interests: The authors declare the absence of obvious and potential conflicts of interest related to the publication of this article

The content is available under Creative Commons Attribution 4.0 License.

$\bowtie$ Viatcheslav Yu. Ratnikov, e-mail: vratnik@yandex.ru 


\section{REFERENCES}

1. Shik S. M., Tesakov A. S., Agadjanyan A. K., Iosifova Yu. I., Markova A. K., Pisareva V. V., Semenov V. V. Proekt regional'noi stratigraficheskoi shkaly eopleistocena i gelazia (paleopleistotsen) tsentra i yuga Evropeiskoi Rossii [Draft regional stratigraphic scale of the Eopleistocene and Gelazian (Paleopleistocene) of center and south of European Russia]. Bulleten' regional'noi mezhvedomstvennoi stratigraficheskoi komissii po Tsentru i yugu Russkoi platformy. [Bulletin of the Regional Interdepartmental Stratigraphic Commission for the Center and South of the Russian Platform], 2015, no. 6, pp. 97-107. (In Russ.)

2. Agadjanyan A. K. Melkie mlekopitayushchie pliotsen-pleistotsena Russkoi ravniny [Pliocene-Pleistocene Small Mammals of the Russian Plain]. Trudy Paleontologicheskogo Instituta RAN [The work of the Paleontological Institute of RAS], Moscow, Nauka, vol. 289, 2009, 676 p. (In Russ.)

3. Agadjanyan A. К., Глушанкова Н. И. Paleogeografiya pliotsen-pleistotsena verchnego Dona. [Paleogeography of the Pliocene-Pleistocene of the Upper Don]. Bulletin of the Commission for Study of the Quaternary. Moscow, GIN, 1988, no. 57, pp. 6277. (In Russ.)

4. Shik S. M., Agadjanyan A. K., Iosifova Yu. I., Markova A. K., Pisareva V. V., Semenov V. V., Tesakov A. S. Proekt regional'noi stratigraficheskoi shkaly eopleistocena tsentra i yuga Vostochno-Evropeiskoi platformy. [Draft regional stratigraphic scale of the Eopleistocene of the center and southeast of the East European platform]. Fundamental'nye problemy kvartera, itogi izucheniya $i$ osnovnye napravleniya dal'neishikh issledovanii [Fundamental problems of quaternary, results and main trends of future studies], Irkutsk, September 15-20, 2015, p. 505-507. (In Russ.)

5. Ratnikov V. Yu. Beskhvostye amfibii pozdnego kainozoya Vostochno-Evropeiskoi platformy i ikh stratigraficheskoe i paleogeograficheskoe znachenie. [Tailless amphibians of the Late $\mathrm{Ce}$ nozoic of the East European Platform and their stratigraphic and paleogeographic significance]. Voronezh, VINITI, 1994. $140 \mathrm{p}$. (In Russ.)

6. Szyndlar Z. Fossil snakes from Poland. Acta zool. cracov., 1984. vol. 28, no 1, pp. 1-156.

7. Evans S. E. The skull of lizards and Tuatara. Biology of the Reptilia, 2008, vol. 20, The skull of Lepidosauria, pp. 1-347.

8. Ratnikov V. Yu. K identifikatsii zherlianok (Bombina, Discoglossidae) po elementam skeleta pri paleontologicheskikh issledovaniyakh [To identification of toads (Bombina, Discoglossidae) by skeletal elements in paleontological studies] $A k$ tual'nye problemy gerpetologii i toksinologii [Actual problems of herpetology and toxinology]. Tol'yatti, 2003, no. 6, pp. 91101. (In Russ.)

9. Ratnikov V. Yu. Pozdnekainozoiskie zemnovodnye i cheshuichatye presmykayushchiesya Vostochno-Evropeiskoi ravniny. [Late Cenozoic amphibians and scaly reptiles of the East European Plain]. Trudy Nauchno-issledovatel'skogo Instituta Geologii [The work of the Research Institute of Geology], Voronezh, VSU Publ., vol. 10, 2002, 138 p. (In Russ.)

10. Villa A., Roček Z., Tschopp E., van den Hoek Ostende L. W., Delfino M. Palaeobatrachus eurydices, sp. nov. (Amphibia, Anura), the last Western European Palaeobatrachid. Journal of Vertebrate Paleontology. 2016, vol. 36, no. 6, pp. 1-15.

11. Špinar Z. Tertiary Frogs from Central Europe. Prague: Academia, 1972, $286 \mathrm{p}$.

12. Hossini S., Rage J.-C. Palaeobatrachid frogs from the earliest Miocene (Agenian) of France, with description of a new species. Geobios, 2000, vol. 33, no. 2, pp. 223-231.

13. Venczel M., Codrea V., Fărcaş C. A new palaeobatrachid frog from the early Oligocene of Suceag, Romania. Journal of Systematic Palaeontology, 2013, vol. 11, no 2, pp. 179-189.
14. Sanchiz B., Młynarski M. Remarks on the fossil anurans from the Polish Neogene. Acta zool. cracov., 1979, vol. 24, no. 1-4, pp. 153-173.

15. Wuttke M., Přikryl T., Ratnikov V. Yu., Dvořák Z., Roček Z. Generic diversity and distributional dynamics of the Palaeobatrachidae (Amphibia: Anura). Palaeobiodiversity and Palaeoenvironments, 2012, vol. 92, no. 3, pp. 367-395.

16. Ratnikov V. Yu. The first find of a Pliobatrachus (Anura, Palaeobatrachidae) in muchkapian sediments of the Don Basin. Pale ont. Zhurn., 1993, no. 4, pp. 130-132. (In Russ.)

17. Ratnikov V. Yu. Rannepleistotsenovaya gerpetofsuna iz mestonakhozhdeniya Kozii Ovrag $\mathrm{v}$ basseine Verkhnego Dona. [Early Pleistocene herpetofauna from the Koziy Ovrag locality in the Upper Don basin]. Izv. vuzov. Geologiya i razvedka $=$ Proceedings of universities. Geology and exploration, 1996, no. 6, pp. 16-19. (In Russ.)

18. Ratnikov V. Yu. The Late Pliocene herpetofauna of the Korotoyak site the Voronezh region and the contemporary lanscape. The down of the Quaternary: Abstracts of the INQUA-SEQS symposium, 16-21 June 1996, Kerkrade, The Netherlands, p. 79.

19. Ратников В. Ю. On the finds of Pliobatrachus (Anura, Palaeobatrachidae) in Eastern Europe. Paleintological Journal, 1997, vol. 31, no. 4, pp. 415-421.

20. Ratnikov V. Yu. Pliocene anurans of East-European platform. Russian journal of herpetology, 2001, vol.8, no 3, pp. 171-178.

21. Ratnikov V. Yu. Muchkapian (Early Neopleistocene) Amphibians and Reptiles of the East-European plain. Russian journal of herpetology, 2002, vol.9, no. 3, P. 229-236.

22. Ratnikov V. Yu. Novye nakhodki zemnovodnykh і и presmykayushchikhsya $\mathrm{v}$ opornykh muchkapskikh mestonakhozhdeniyakh basseina Verkhnego Dona [New finds of amphibians and reptiles in the reference Muchkap localities of the Upper Don basin]. Vestnik Voronezhskogo gosudarstvennogo universiteta. Seriya: Geologiya = Proceedings of Voronezh State University. Series: Geology, 2002, no. 1, pp. 73-79. (In Russ.)

23. Ratnikov V. Yu. Novye nakhodki zemnovodnykh і и presmykayushchikhsya iz nizhneneopleistotsenovogo mestonakhozhdeniya Il'inka [New Finds of Amphibians and Reptiles from the Lower Neopleistocene Ilyinka Locality]. Vestnik Voronezhskogo gosudarstvennogo universiteta. Seriya: Geologiya $=$ Proceedings of Voronezh State University. Series: Geology, 2003, no. 1, pp. 36-39. (In Russ.)

24. Ratnikov V. Yu. Osteology of Russian toads and frogs for palaeontological researches. Acta zool. cracov., 2001, vol. 44, no. 1 , pp. 1-23.

25. Ratnikov V. Yu. Osteologicheskie kharakteristiki nadvidovykh taksonov zhab i lyagushek Vostochnoi Evropy [Osteological characteristics of supraspecific taxa of toads and frogs of Eastern Europe] Voprosy gerpetologii: materialy pyatogo s'ezda Gerpetologicheskogo obshchestva im. A.M. Nikol'ckogo [Questions of herpetology: materials of the Fifth Congress of the Herpetological Society named after A.M. Nikolsky], Minsk, September 25-28, 2012, pp. 269-273. (In Russ.)

26. Čerňansky' A., Syromyatnikova E. V. The first Miocene fossils of Lacerta cf. trilineata (Squamata, Lacertidae) with a comparative study of the main cranial osteological differences in green lizards and their relatives. PLOS ONE, 2019, vol.14, no. 8: e0216191, pp. 1-55.

27. Vorob'eva E. I., Chugunova T. Yu. Zubnaya sistema yashcherits: taksonomicheskoe i ekologicheskoe raznoobrazie. [Dental system of lizards: taxonomic and ecological diversity]. Moscow, Nauka, 1995, 151 p. (In Russ.)

28. Goncharov A. G. O rasprostranenii yashcherits (Sauria) v Tsentral'nom Chernozem'e. [About the distribution of lizards 
(Sauria) in the Central Black Earth Region]. Sovremennaya gerpetologiya: problemy i puti ikh resheniya. Stat'i po materialam dokladov Pervoi mezhdunarodnoi molodezhnoi konferentsii gerpetologov Rossii i sopredel'nykh stran. [Modern herpetology: problems and solutions. Articles based on the materials of the reports of the First International Youth Conference of Herpetologists in Russia and neighboring countries]. Saint-Peterburg, Russia, November 25-27, 2013, pp. 72-76. (In Russ.)

29. Ratnikov V. Yu. Gerpetofauna iz sredneneopleistotsenovogo mestonakhozhdeniya Ruchei Kolabinsky (Kursraya oblast'). [Herpetofauna from the Late Middle Pleistocene locality of Kolabinsky brook (Kursk region). Vestnik Voronezhskogo gosudarstvennogo universiteta. Seriya: Geologiya $=$ Proceedings of Voronezh State University. Series: Geology, 2019, no. 2, pp. 36-42. (In Russ.)

30. Szyndlar Z. A review of Neogene and Quaternary snakes of Central and Eastern Europe. Part II: Natricinae, Elapidae, Viperidae. Estudios geol., 1991, vol. 47, pp. 237-266.

31. Auffenberg W. The fossil Snakes of Florida. Tulane Studies Zool., 1963, vol. 10, no 3, pp. 131-216.

32. Ratnikov V. Yu. Identification of some Eurasian species of Elaphe (Colubridae, Serpentes) on the basis of vertebrae. Russian Journal of Herpetology, 2004, vol. 11, no. 2, pp. 91-98.

33. Ratnikov V., Mebert K. Fossil remains of Natrix tessellata from the Late Cenozoic deposits of the East European Plain. Mertensiella, 2011, no. 18, pp. 337-342.

34. Ananjeva N. B., Orlov N. L., Khalikov R. G., Darevsky I. S., Ryabov S. A., Barabanov A. V. The Reptiles of Northern Eurasia (Taxonomic Diversity, Distribution, Conservation Status). SaintPetersburg, Zoological Institute RAS, 2006, 245 p.
35. Ivanov M. The first European pit viper from the Miocene of Ukraine. Acta Palaeontologica Polonica, 1999, vol. 44, no. 3, pp. 327-334.

36. Ratnikov V. Yu. Gerpetofauna nizhnepleistotsenovogo mestonakhozhdeniya Vol'naya Vershina $\mathrm{v}$ basseine Verkhnego Dona [Herpetofauna of the Lower Pleistocene locality Volnaya Vershina in the Upper Don basin]. Vestnik Voronezhskogo gosudarstvennogo universiteta. Seriya: Geologiya = Proceedings of Voronezh State University. Series: Geology, 1996, no. 1, pp. 90-93. (In Russ.)

37. Ratnikov V. Yu. Eopleistocene and Pleistocene Anurans of the East-European Platform. Paleont. Zhurn., 1992, no. 1, pp. 89100. (In Russ.)

38. Ratnikov V. Yu. Novye dannye o gerpetofaune mestonakhozhdeniya Kuznetsovka v Tambovskoi oblasti. [New data on the herpetofauna of the Kuznetsovka locality in the Tambov region]. Izv. vuzov. Geologiya i razvedka = Proceedings of universities. Geology and exploration, 1997, no. 1, pp. 26-32. (In Russ.) 39. Ratnikov V. Yu. Fossil remains of modern amphibian and reptile species as the material for studying of their areas history. Trudy Nauchno-issledovatel'skogo Instituta Geologii [The work of the Research Institute of Geology], Voronezh, VSU Publ., vol. 59, 2009, 91 p. (In Russ.).

40. Ratnikov V. Yu. Gerpetofauna verkhnepleistotsenovogo mestonakhozhdeniya Elasy $\mathrm{v}$ basseine Volgi. [Herpetofauna of the Upper Pleistocene Elasy locality in the Volga basin]. Aktual'nye problemy gerpetologii i toksinologii [Actual problems of herpetology and toxinology]. Tol'yatti, 2001, no. 5, pp. 81-88. (In Russ.)
Ратников Вячеслав Юрьевич - д. г.-м. н., профессор, Воронежский государственный университет, Воронеж, Российская федерация; E-mail: vratnik@yandex.ru; ORCID http://orcid.org/0000-0002-7723-5356

Автор прочитал и одобрил окончательный вариант рукописи.
Viatcheslav Yu. Ratnikov - PhD, Dr. habil. in Geol.-Min, Professor, Voronezh State University, Voronezh, Russian Federation; E-mail: vratnik@yandex.ru;

ORCID http://orcid.org/0000-0002-7723-5356

Author have read and approved the final manuscript. 